\title{
EKSISTENSI KESENIAN TA'BUTHAAN SERTA RELASI KUASA ANTAR AKTOR DALAM KESENIAN TA'BUTHAAN
}

\author{
Dwi Retnaning Putri ${ }^{1}$, Retno Sukma Wanti ${ }^{2}$, Fikry Rohmatul Jannah ${ }^{3}$, \\ Andini Kurniasih ${ }^{4}$, Alfinna Bella Nathassya ${ }^{5}$
}

\author{
1)2)3)4)5) Universitas Jember \\ alfinnabella1608@gmail.com
}

Received: 8 December 2019 | Reviewed: 29 December 2019 | Accepted: 28 January 2020

\begin{abstract}
ABSTRAK
Budaya ta'butha'an adalah budaya khas yang berasal dari Desa Kamal Kecamatan Arjasa kesenian khas Jember Utara yang hingga saat ini kesenian tersebut masih terus dilestarikan dan menjadi ikon desa kamal itu sendiri. Kesenian Ta'butha'an rutin pada umum digunakan dalam acara resik desa, yang biasanya diakukan setiap tahun, yang pada saat ini masih sering ditampilan dalam berbagai acara yang di selenggrakan khususnya oeh masyarakat desa Kamal. Penelitian ini membahas tentang eksistensi dari kesenian Ta'butha'an, selain itu juga tentang bagaimana relasi para aktor yang berkuasaan pada kesenian Ta'butaan. Relasi kekuasaan ini merupakan sebuah fenomena yang pasti ada dalam suatu masyarakat. Relasi ini timbul karena adanya interaksi dalam masyarakat, yang pada akhirnya akan menimbulkan suatu dominasi tertentu. Kekuasaan didapatkan oleh seseorang atau kelompok tertentu dikarenakan adanya faktor-faktor pendukung adanya dominasi tersebut. Metode yang digunakan ialah penelitian kualitatif dengan pendekatan deskriptif analitis. Dalam penelitian ini teknik pengambilan data yang digunakan adalah observasi dan wawancara mendalam terhadap informan terpilih. Data di analisis melalui teknik analisis kritis menggunakan teori Michael Foucault mengenai konsep kekuasaan. Akhirnya praktik itu dapat di analisis dan di pandang sebagai sebuah kajian ilmiah dalam bidang akademis.
\end{abstract}

Kata Kunci : Budaya, Ta'Buthaan, Kuasa, Relasi

Korespondensi:

Universitas Jember

Kampus Tegalboto, Jl. Kalimantan No.37

Krajan Timur, Kabupaten Jember, Jawa Timur

E-mail: alfinnabella1608@gmail.com 


\begin{abstract}
Ta'butha'an culture is a unique culture originating from Kamal Village, Arjasa Subdistrict, the typical art of North Jember, which until now the art continues to be preserved and become an icon of the Kamal village itself. Ta'butha'an art is routinely used in village rehearsal events, which are usually held every year, which at this time are still often performed in various events organized especially by the Kamal villagers. This research discusses the existence of Ta'butha'an art, besides also about how the relation of the actors who have power in Ta'buta art. This power relation is a phenomenon that certainly exists in a society. This relationship arises because of interactions in society, which in turn will lead to a certain dominance. Power is obtained by a certain person or group due to the supporting factors of the existence of such domination. The method used is qualitative research with a descriptive analytical approach. In this study the data collection techniques used were observation and in-depth interviews with selected informants. Data were analyzed through critical analysis techniques using Michel Foucault's theory of power concepts. Finally, the practice can be analyzed and viewed as a scientific study in the academic field.
\end{abstract}

Keywords: Culture, Ta'Buthaan, Power, Relations.

\title{
PENDAHULUAN
}

Indonesia merupakan negara yang memiliki beraneka ragam budaya, tradisi, adat istiadat, serta kesenian kesenian yang dimiliki oleh para penduduk nya. Di setiap daerah memiliki keunikan budaya khas masing masing, terutama di Kabupaten Jember memiliki keunikan nya sendiri, yaitu budaya pandalungan. Secara budaya, yang disebut masyarakat pandalungan adalah masyarakat hibrida, yakni masyarakat berbudaya baru akibat terjadinya percampuran dua budaya dominan, kedua budaya tersebut adalah budaya yang berasal dari etnik Jawa dan juga etnik Madura yang lebih dominan (Saputri, 2019). Dalam kontes kawasan "tapal kuda" jawa timur, budaya pandalungan adalah percampuran antara dua budaya dominan, yakni budaya jawa dan budaya madura. Pada era sekarang masyarakat luar maupun pendatang di Jember lebih mengenal JFC (Jember Fashion Carnaval) sebagai budaya yang sudah di kenal banyak orang. JFC merupakan sebuah karnaval yang didalamya juga terdapat pertunjukan catwalk yang mana para peraga akan berlaga mengikuti music yang ada (Jannah, 2012).

Padahal di balik kemegahan JFC yang dikenal banyak orang, kota Jember memiliki budaya kesenian tradisional yang masih di lestarikan oleh masyarakat yakni kesenian Tha'Buthaan. Budaya Ta'Buthaan merupakan salah satu budaya tertua yang ada di Kabupaten Jember khususnya Jember bagian utara. Ta'Buthaan berasal dari bahasa Madura, 
yang jika dirubah kedalam bahasa Jawa berarti Butho yang berarti raksasa. Kesenian ini merupakan budaya yang amat bersejarah dalam masa dulu di kabupaten Jember, namun seiring berkembangnya zaman budaya-budaya tradisonal seperti ini mulai luntur dimakan waktu. Hanya masyarakat yang memiliki semangat pelestari kesenian lah yang masih mau melestarikan atau tetap berusaha memperkenalkan budaya tradisional kepada penerus atau anak cucu mereka. Tak semua masyarakat Jember mengenal budaya ini terlebih para generasi muda yang tidak diberi pengetahuan atas hal ini, para generasi muda cenderung menyibukkan diri dengan kehidupan media sosialnya dan sangat sedikit yang mau belajar melestarikan budaya khas kota mereka.

Arus globalisasi sangat berpengaruh pada generasi penerus bangsa dimana generasi muda atau masyarakat lebih menyukai budaya dari luar yang dipandang lebih kekinian dan banyak peminatnya, selain itu juga mengikuti trend masa kini di lingkungan masyarakat yang semakin modern. Berdasarkan realita yang ada sangat disayangkan jika budaya atau tradisi yang menjadi ikon atau ciri khas sebuah kota perlahan menghilang tanpa di lestarikan kembali dan dikenalkan kepada para penerus generasi. Karena budaya juga produk dari peninggalan para sesepuh yang dulunya menjadi generasi pertama yang membabat desa. Jika tidak ada masyarakat atau individu yang memiliki inisiatif sendiri untuk tetap melestarikan suatu budaya maka bisa dipastikan budaya hanya menjadi sejarah yang hanya dinikmati pembaca tidak bisa disaksikan kembali.

Walaupun pada kenyataannya tidak di pungkiri lagi kita hidup di zaman modern dan tidak bisa mempratikkan tradisi secara sempurna setidaknya masyarakat masih bisa menikmati terlepas dari unsur-unsur kesempurnaan kesenian itu sendiri termasuk tata cara yang mungkin dulu sangat sakral bisa menjadi sebatas tontonan masyarakat saja. Tetapi lestarinya suatu budaya di masyarakat modern tidak terlepas dari aktor-aktor yang berjuang untuk tetap mengenalkan suatu kesenian tradisonal ke masyarakat. selain itu pengaruh aktor sangatlah kuat, dimana aktor disini merupakan pemilik sanggar kesenian dan juga para pemain yang terlibat, disini dapat dilihat bagaimana cara aktor tetap bisa menggaet para pemuda maupun masyarakat lintas umur untuk tetap mau bergelut didunia kesenian tardisional walaupun tidak menentu penghasilan yang di dapat nantinya.

Aktor dalam kesenian ini memiliki peran masing-masing dimana ada pihak yang memiliki power lebih semisal untuk mengelola atau mengatur pemain. Setiap lembaga yang berdiri pasti memiliki struktur dan tiap struktur terdapat peran dan power yang berbeda disinilah letak bagaimana kekuasaan bisa mempengaruhi eksistensi suatu budaya di masyarakat. relasi antar aktor yang tercipta biasanya sudah turun temurun dari para 
pendahulunya dan mereka tinggal melanjutkan sebagai generasi penerus yang harus siap melestarikan budaya nenek moyang tersebut. Namun ada pula yang tidak memiliki kecondongan pada hal yang berbau seni misalnya disinilah nanti fungsi pemilik sanggar atau orang yang lebih berkuasa menciptakan cara atau inisiatif agar generasi mudanya tetap mau menjadi pelestari seni tanpa mengganggu kegiatannya yang lain. Begitu juga relasi antar pemilik sanggar kesenian, tentu saja tak hanya satu orang saja yang jadi pelestrai disini tetapi juga pasti ada teman atau rekan pejuang yang sama, relasi yang tercipta anata pemilik sanggar bisa mempengaruhi eksistensi budaya juga. Karena pola yang diciptakan untuk memperkenalkan kesenian tersebut ke masyarakat juga berbeda bahkan citra yang di bentuk juga berbeda.

\section{KAJIAN TEORI}

Penelitian kali ini peneliti menggunakan acuan dari perspektif Michel Foucault yaitu teori tentang konsep kekuasaan. Di sini ide kekuasaan Foucault di gambarkan seperti pemerintahan dan peran-perannya, yang bekerja sebagai kelas sosial yang berkuasa, sebagai tata laksana kapitalisme atau sebagai lembaga biasa yang tersebar di masyarakat yang mempengaruhi kehidupan manusia setiap hari. Dalam konsepnya tentang relasi kekuasaan Foucault juga membahas tentang strukturalisme yang ada di di masyarakat, menurutmya strukturalisme yang berkembang di masyarakat memiliki dua kelemahan. Pertama, strukturalisme hanya bisa menganalisis relasi-relasi dalam satuan periode sejarah sehingga ia tidak bisa memahami keseluruhan makna. Kedua, strukturalisme tidak mampu menjelaskan kasus perubahan-perubahan radikal dan ide tentang diskontinuitas. Hal ini berarti bahwa sistem punya banyak pintu keluar dan setiap saat jalan sejarah bisa saja memilih keluar dari jalannya sistem yang ada. Setiap subjek berhak memilih satu dan berhak menolak lainnya ketika berdasarkan naluri subjektifnya salah satu faktor dianggap lebih penting.

"Foucault meringkas gagasannya tentang power : pertama, mendesentralisasi power yang terpusat. Kedua, mempelajari bentuk-bentuk power yang dimiliki, diajukan dan dampaknya. Dengan menolak power yang terpusat, maka power bukan dianggap sebagai komoditas yang dimiliki atau sebagai rezim dominasi antara yang kuat dengan yang lemah. Power menyebar dalam jaringan sekaligus objek dari power (Foucault, 2002b:29). Power tidak bekerja dari atas kebawah akan tetapi dari bawah keatas, mulai dari ide, penerapanperincian pada skala kecil lalu keputusan dan tindakan besar. Bukan bertolak 
dari ideologi akan tetapi pengetahuan dan praktik yang membuat ide/gagasan itu mungkin dilaksanakan." (Lubis, 2016:81)

Menurut Foucault kuasa itu ada dimana-mana dan muncul dari relasi-relasi antara berbagai kekuatan terjadi secara mutlak dan tidak tergantung dari kesadaran manusia. Kekuasaan hanyalah sebuah strategi, strategi ini berlangsung dimana-mana dan disana terdapat sistem, aturan, susunan dan regulasi. Kekuasaan ini tidak datang dari luar melainkan kekuasaan menentukan susunan, aturan dan hubungan-hubungan dari dalam dan memungkinkan semuanya terjadi. Seperti halnya kajian relasi kuasa yang akan dijelaskan dalam penlitian ini, dimana dalam setiap sanggar pasti terdapat aktor yang mendominasi (pemimpin) sanggar tersebut. Dengan menggunakan teori kekuasaan ini dapat dilihat mengenai bagaimana kekuasaan tersebut bekerja dan bagaimana seorang actor tersebut dapat berkuasa.

Disini Foucault menunjukan hubungan antara diskursus ilmu pengetahuan dengan kekuasaan. Foucault melihat praktik pengkaplingan yang memisah-misah kan orang-orang yang sakit dari orang sehat, yang normal dari yang tidak normal merupakan salah satu bentuk aplikasi kekuasaan seseorang atau satu kelompok orang atas yang lain. Konsep ini digunakan dalam menganalisis relasi kekuasaan pada kesenian Ta'Buthaan yaitu menegenai bagaimana aktor yang berkuasa menjaankan perannya dan dalam lingkup yang seperti apa. Menurut Foucault ada dua pendapat penting saat pengetahuan bertemu dengan pikiran-pikiran tentang kemanusiaan. Pertama, dengan pengetahuannya sendiri manusia merupakan makhluk yang dibatasi oleh lingkungan sekitarnya. Kedua, rasionalitas dan kebenaran selalu berubah sepanjang sejarah.

“kekuasaan adalah sesuatu yang dilegitimasikan secara metafisis kepada negara yang memungkinkan negara dapat mewajibkan semua orang untuk memetuhinya.namun menurut Foucault, kekuasaan bukanlah sesuatu yang hanya dikuasai oleh negara, sesuatu yang dapat diukur. kekuasaan ada di mana- mana karena kekuasaan satu dimensi dari relasi” (Af, 2012)

Berbeda dengan para pemikir lain yang telah menguraikan konsep-konsep kekuasaan, Foucault menampilkan suatu perspektif kekuasaan secara baru. Menurut Foucault kekuasaan bukanlah sesuatu yang hanya dikuasai oleh negara, sesuatu yang dapat diukur. Kekuasaan bagi dia ada dimana-mana, karena kekuasaan merupakan satu dimensi dari relasi. Artinya, dimana ada relasi, disana ada kekuasaan. Disinilah letak kekhasan Foucault, dia tidak menguraikan apa itu kuasa tetapi bagaimana kuasa itu berfungsi pada bidang tertentu. Dalam 
masyarakat akan selalu ditemukan konsep kekuasaan tetapi juga tergantung pada bagaimana Sebenernya yang hendak dibuat Foucault adalah menunjukan bahwa kita adalah bagian dari mekanisme kekuasaan itu.

Dari kesadaran ini akan lahir dari kesadaran akan tempat diri sendiri dalam konstelasi kekuasaan. Yang menjadi masalah dalam kehidupan adalah bahwa banyak orang tak menyadari perannya dalam peta kekuasaan. Apabila orang sadar akan hal ini, maka orang pun akan menerima dan menghargai pluralitas peran yang ada dalam relasi kekuasaan. Dari ketidaksadaran ini akan lahir berbagai tindakan dan sistem yang menindas dan menyeragamkan. Teori diatas serta penjelasannya merupakan tinjauan yang akan peneliti gunakan untuk mengkaji masalah yang akan diteliti dalam penelitian kali ini. Dimana disini konsep kekuasaan Foucault digunakan untuk menganalisa relasi kuasa dalam kesenian Ta'Buthaan, termasuk juga relasi antar aktor didalamnya. Konsep-konsep yang digunakan untuk menganalisa hasil data penelitian ini ditinjau dari teori yang sudah peneliti jelaskan sebelumnya.

\section{METODE PENELITIAN}

\section{Setting lokasi, setting sosial, dan waktu penelitan}

a. Setting lokasi

Penelitian ini mengambil setting lokasi di Kecamatan Arjasa, Jember, dan juga di desa sekitar yang berada di Kecamatan Arjasa meliputi Desa Kamal, Desa Candi Jati dan Desa Patemon. Kecamatan Arjasa merupakan tempat dimana kesenian Ta 'Buthaan berkembang dan berjalan tepatnya di Desa Kamal. Jika ditarik hubungan dengan penelitian ini adalah karena Kecamatan Arjasa merupakan tempat budaya Ta 'Buthaan muncul pertama kali dan berkembang. Kesenian Ta 'Buthaan memang tumbuh di daerah Timur kota Jember. Sesuai dengan topik penelitian yang akan dikaji kesenian $\mathrm{Ta}$ 'Buthaan merupakan kesenian khas budaya timur. Sehingga dalam hal ini akan lebih mudah mendapatkan informan untuk mendapatkan informasi yang dibutuhkan dalam penelitian.

\section{b. Setting sosial}

Setting sosial merupakan salah satu instrument untuk menjelaskan keadaan sosial dari penelitian yang akan dilakukan. Dalam penelitian ini setting sosial yang nampak adalah mengenai tentang bagaimana relasi kekuasaan pada kesenian budaya ta'butaan. Relasi kekuasaan ini merupakan sebuah hubungan yang ada pada setiap jenis masyarakat, dalam penelitian ini sendiri dilakukan pada lingkungan yang ada relasi antar aktor dalam kesenian 
yang. Kekuasaan juga dapat terjadi dalam berbagai bidang kehidupan sebagai konsekuensi dari adanya hubungan/interaksi dalam masyarakat, yang salah satunya mengenai relasi kekuasaan dalam bidang budaya yang akan dibahas dalam penelitian ini.

c. Waktu penelitian

Waktu penelitian dalam penelitian ini adalah waktu dimana seorang penenliti akan melakukan penelitian/penggalian data. Dalam penelitian ini di butuhkan pengambilan data melalui wawancara salah satunya, sehingga dalam menentukan waktu penelitian harus mempertimbangkan dimana peneliti dapat dengan mudah mendapatkan informasi dari informan. Waktu yang diambil peneliti untuk meneliti penelitian adalah waktu pada saat kesenian $\mathrm{Ta}$ 'Buthaan dilaksanakan. Juga peneliti mengambil waktu diluar kesenian tersebut untuk mengunjungi informan yang berkaitan dengan kesenian Ta 'Buthaan. Waktu tersebut dilakukan secara konsisten sehingga data yang diperoleh juga semakin kompleks. Dalam penelitian ini pemilihan hari penelitian dilakukan ketika hari libur kegiatan perkuliahan. Pemilihan ini dengan pertimbangan bahwa, ketika hari libur peneliti dapat lebih leluasa dalam mencari melakukan wawancara dengan informan. Pengambilan waktu ini dengan harapan agar peneliti dapat dengan mudah melakukan penggalian data.

\section{Pendekatan penelitian}

Penelitian yang akan dilakukan merupakan penelitian dengan pendekatan studi kasus. Dalam sebuah literature pendekatan studi kasus di devinisikan sebagai berikut :

"Riset studi kasus dimulai dengan mengidektifikasi satu kasus yang spesifik. kasus ini dapat berupa entitas yang konkrit misalnya individu, kelompok kecil, organisasi, atau kemitraan. .... kuncinya disini adalah untuk mendefinisikan kasus yang dapat dibatasi atau dideskripsikan dalam parameter tertentu." (Creswell, 2015)

Dalam penelitian kaulitatif, pendekatan studi kasus ini lebih berfokus pada masalah-masalah yang memang terjadi pada masyarakat. Penelitian studi kasus bertujuan untuk mengjelaskan kasus yang ada secara lebih terperinci dengan fokus-fokus penelitian yang telah dikhususkan. Dengan melakukan penelitian ini, maka akan diperoleh kejelasan/pemahaman secara mendalam mengenai kasus yang menjadi topik penelitian seorang peneliti. Dalam penelitian ini misalnya, kasus yang akan diteliti yaitu mengenai relasi kekuasaan pada kesenian budaya ta'butaan. Relasi kekuasaan ini merupakan sebuah hubungan yang ada pada setiap jenis 
masyarakat. Penelitian studi kasus akan membongkar kasus tersebut, sehingga akan diperoleh kejelasan mengenai bagaimanakah kekuasaan yang terjadi dalam berbagai bidang kehidupan sebagai konsekuensi dari adanya hubungan/interaksi dalam masyarakat, yang salah satunya mengenai relasi kekuasaan dalam bidang budaya yang akan dibahas dalam penelitian ini.

\section{Teknik Pengambilan data}

Teknik pengambilan data dalam penelitian menggunakan 3 cara, yaitu

\section{a. Observasi lapangan}

Observasi dilakukan untuk melakukan pengamatan lebih dekat untuk melihat perilaku subyek penelitan dan juga mengani lokasi dimana akan dilakukan penggalian data lebih dalam lagi. Selain itu obeservasi juga dilakukan untuk memberikan informasi yang valid mengenai kondisi sosial dimana penelitian ini berlangsung. Dalam hal ini tentu saja peneliti melakukan kegiatan observasi lapangan di daerah kesenian Ta'Buthaan berada terutama saat kesenian itu dipertunjukan kepada masyarakat.

\section{b. Wawancara}

Teknik pengambilan data berikutnya yang digunakan adalah dengan melakukan wawancara dengan informan. Wawancara merupakan salah satu cara untuk menggali data yang bersifat primer. Dimana dalam wawancara peneliti lebih dekat dengan informan karena melakukan pendekatan secara langsung dengan demikian peneliti juga mampu melihat ekspresi yang diperlihatkan oleh informan, karena melalui ekspresi juga peneliti bisa melihat data yang di ambil benar atau tidak. Data inilah nantinya yang aka di analisis yang kemudian akan dibandingkan atau dikonversi dengan data-data yang didapatkan lainnya, Sehingga dalam hal ini akan memudahka peneliti untuk melakukan analisis.

c. Analisis dokumentasi

Dokumentasi disini merupakan data berbentuk visual sebagai data pendudukung untuk data-data primer sebelumnya. Dalam dokumentasi ini akan memberika lebih jelas lagi mengenai gambaran sosial yang bahkan telah berlalu. Dokumetasi disini juga akan memberikan suatu pengalaman tertentu pada anggota yang lain.

\section{Penentuan Informan}

Dalam sebuah penelitian/topik penelitian memiliki caranya masing-masing untuk menentukan informannya. Dalam penelitian ini teknik sampling yang digunakan yaitu menggunakan purposif sampling. Secara sederhana, purposive sampling merupakan teknik sampling non random. Non random disini berarti informan yang dipilih harus memenuhi 
kualifikasi/ standart-standart yang telah ditentukan oleh peneliti tersebut. Jika di kaitkan dengan penelitian ini tentu saja yang mejadi informan penelitian ini ialah oknum-oknum yang bersangkutan atau memiliki peran dalam kesenian Ta'Buthaan.

\section{Teknik Analisis Data}

Dalam melakukan analisis data, penelitian ini menggunakan teknik triangulasi data. Dalam sebuah literature, teknik triangulasi dijelaskan sebagai sebuah teknik yang lebih menekankan untuk mencari validits data, triangulasi dapat pula dikataknsebagi pendekatan multimetode (Hadi, 2016). Teknik triangulasi ini dilakukan dengan cara membandingkan antara kenyataan di lapangan dengan data yang diperoleh oleh si Peneliti.

\section{PEMBAHASAN}

\section{Sejarah budaya ta'buthaan}

Budaya Ta'Buthaan merupakan salah satu budaya tertua yang ada di Kabupaten Jember khususnya Jember bagian utara. Ta'Buthaan berasal dari bahasa Madura, yang jika dirubah kedalam bahasa Jawa berarti Butho yang berarti raksasa. Budaya ini merupakan budaya lokal maysrakat setempat yang memiliki banyak makna dan juga filosofi. Dalam sejarah desa kesenian Ta'Buthaan ini dilakuka ketika memasuki masa panen raya kedua. hal ini dilakukan karena masyarakat percaya bahwa kesenian Ta'Buthaan mampu mengusir halhal buruk yang akan memperngaruhi pertanian mereka, sehingga masyarakat setempat bisa medapatkan hasilpanen yang melimpah. Selain dalam event panen raya, kesenian Ta'Buthaan ini juga sering ditampilkan dalam acara resik desa yang dilakukan secara rutin setiap tahunnya. Kesenian ini memiliki tujuan untuk menolak bala, maka dari itu dalam agenda patennya selalu berhubungan dengan perlindungan dan pembersihan.

Budaya Ta'Buthaan merupkan representasi dari kejadian masa lampau yang melibatkan sektor perekonomian utama desa yaitu pertanian. Sejarah singkat Ta'Buthaan terjadi ketika disebuah desa sedang terjadi bencana di bidang pertanian yang disebut laep panjang yang merupakan serangan hama wereng pada pertanian desa setempat. bencana tersebut terjadi selama 6 bulan. Ketika itu muncullah keajaiban aneh datang tepatnya di desa Kamal. seorang penduduk bersuami istri dengan tangan terikat dipinggang dengan menarinari dengan iringan bunyi lesung panjang yang ditumbuk orang untuk menghaluskan padi atau rojengan. Ketika itu maka laep panjang berakhir dan panen menghasilkan hasil yang melimpah. budaya Ta'Buthaan sendiri merupakan salah satu represetasi dari kesah tersebut 
yang dicetuskan oleh Ki Samba pada saat itu. Ta'Buthaan dibuat dari bahan dasar kayu atau bambu dengan ornament dan busana seperti layaknya manusia.

Sebagaimana dengan nama yang diberikan yaitu Ta'Buthaan, yang identik dengan paras yang menyeramkan sehingga topeng Ta'Buthaan di desain sedemikian rupa sehingga memiliki tampilan yang menyeramkan. Dalam pelaksanaan atau pementasan kesenian tersebut masih menggunakan ritual-ritual yang melibatkan banyak kebutuhan. Kebutuhan tersebut misalnya kue-kue tradisional, kembang 7 rupa, dan bahan-bahan pelengkap lainnya. selain itu juga dilakukan ritual-ritual yang dilakukan sebelum pementasan dimulai. Tujuan dari adanya ritual tersebut adalah untuk mengisi para pemain agar ketika melakukan pementasan tersebut tidak mengalami kendala yang tidak diinginkan (Andiyanto, 2003). Dalam perkembangannya, budaya ini juga mengalamai banyak sekali penyesuaian. Mulai dari instrument musik, kostum, hingga pementasannya. Jika pada masa lampau kesenian Ta'Buthaan dianggap sebagai kesenian yang sakral dan menakutkan, pementasannya pun hanya dilakukan pada saat panen raya dan juga resik desa. Pada era sekarang justru Ta'Buthaan menjadi kesenian yang biasa tampil dalam segala acara. Misalnya dalam acara pernikahan, khitanan, arisan, dan lain sebagainya. Dari segi instrumennya juga sudah mengalami modifikas dengan menyesuaikan dengan lagu-lagu yang sedang digemari pada masanya.

\section{Eksistensi kesenian ta 'buthaan dalam era modern}

Eksistensi berasal dari kata bahasa latin yaitu existere yang artinya muncul, ada, timbul, memiliki keberadaan aktual. Eksistensi dalam penelitian ini adalah mengenai keberadaan pertunjukan kesenian Ta'Buthaan yang sampai saat ini masih mempu bertahan ditengah kehidupan di era modern ini. Sehingga eksistensi yang dimaksudkan di sini ialah sebuah keberadaan dan ketahanan kelompok yang mampu berkembang dan memiliki pola pikir kreatif agar tetap mendapatkan tempat dihati seluruh masyarakat penggemarnya terutama masyarakat jember (Eska Wiedyana, 2018). Berkembangnya zaman saat ini memiliki dampak yang sangat besar terhadap perkembangan di suatu negara, dampak tersebut dapat berupa dampak positif maupun dampak negatif. Masuknya kebudayaan baru serta teknologi dapat menjadi media dapat menjadi pengembangan cerita-cerita rakyat ke dalam kemasan yang lebih menarik sehingga eksistensi cerita rakyatnya tersebut dapat tetap terjaga dengan baik. Pada dasarnya keberadaan teknologi tersebut justru menyebabkan hilangnya cerita-cerita rakyat di kalangan masyarakat. Generasi muda lebih mengetahui tentang cerita-cerita modern daripada tentang daerahnya sendiri (Hidayah \& Azizah, 2018). 
Cerita rakyat pada umumnya lahir pada daerah-daerah yang memiliki banyak peninggalan prasejarah, seperti cerita rakyat kesenian Ta'Buthaan. kesenian Ta' Buthaan ini berkembang di daerah Jember Utara yang tepatnya berada di Desa Kamal. kesenian $T a$ ' Butha'an tersebut berkembang karena adanya keyakinan yang sangat kuat oleh warga sekitar Desa Kamal mengenai isi dari kesenian Ta'Buthaan tersebut. Kepercayaan warga Desa Kamal terhadap kesenian Ta'Buthaan sampai sekarang masih tetap sama yaitu sebagai warisan budaya lokal yang berada di daerah desa tersebut. kepercayaan akan kesenian Ta'Buthaan tersebut menjadikannya bukan hanya sekedar sebuah cerita dan juga kesenian saja melainkan juga telah menjadi suatu ritual yang selalu rutin dilakukan pada saat acara resik desa setiap tahunnya tepatnya pada saat setelah panen raya kedua. Ritual kesenian Ta'Buthaan tersebut telah menjadi sebuah kebudayaan yang berkembang dan tetap dilestarikan oleh masyarakat Desa Kamal.

Di daerah Jember Utara sendiri terdapat sekitar 23 lebih kelompok sanggar kesenian Ta'Buthaan diantaranya yaitu berada di Desa Jelbuk, Desa Pakusari, Desa Darsono, Desa Arjasa, Desa Candi jati, Desa Panduman, dan termasuk juga Desa Kamal. Di Desa Kamal kesenian Ta'Buthaan masih tetap dilestarikan. Ganerasi muda atau pemuda-pemuda desa tersebut masih turut serta dalam menampilkan kesenian $\mathrm{Ta}^{\prime}$ Buthaan tersebut dalam eventevent yang ada. kesenian Ta'Buthaan di Desa Kamal memiliki acara rutinan yaitu dalam acara resik desa. Penampilan kesenian Ta' Buthaan di acara resik desa tersebut dilakukan setiap tahun tepatnya setelah panen raya kedua di Desa Kamal. Tidak hanya dalam acara resik desa saja, kesenian $T a^{\prime}$ Buthaan tersebut ditampilkan melainkan juga dalam acara-acara seperti pernikahan, arisan, khitanan, dan lain sebagainnya. Banyak masyarakat yang tak segan menampilkan kesenian Ta' Buthaan di acara mereka. kesenian Ta'Buthaan juga sering tampil pada acara karnaval saat memperingati hari kemerdekaan indonesia. Acara-acara tersebut dimaksudkan untuk melesatarikan dan mengembangkan kesenian Ta'Butha'an.

Selain tampil pada acara-acara pernikahan, khitanan, resik desa, arisan dan lain sebagainnya di daerah Jember, kesenian $T a$ ' Buthaan juga sering tampil dan ikut serta dalam event-event diluar kota seperti karnaval di daerah Situbondo, Bondowoso, tuban, dan Surabaya. Beberapa bulan ini kesenian Ta'Buthaan di Desa Kamal tampil pada acara peresmian sanggar kesenian $\mathrm{Ta}$ ' Buthaan duplang nusantara dan ikut serta dalam acara live carnival di Situbondo. Ikut serta dalam event tersebut dimaksudkan agar kesenian $T a$ ' Buthaan dapat berkembang dan di kenal oleh banyak orang di luar kota jember. Oleh karena itu tampil diluar kota dapat meningkatkan eksistensi kebudayaan kesenian Ta' Buthaan agar dapat terus terjaga dengan baik. 
Aktor dalam kesenian kesenian $\mathrm{Ta}^{\prime}$ Buthaan ini memiliki peran masing-masing, ada pihak yang memiliki kuasa lebih dalam mengolah serta mengatur sanggar kesenian $T a$ ' Buthaan. Kekuasaan dapat mempengaruhi suatu budaya kesenian yang ada dimasyarakat. seperti halnya menurut Foucault bahwa kekuasaan bukanlah sesuatu yang hanya dikuasai oleh negara, sesuatu yang dapat diukur namun kekuasaan bagi Foucault ada dimana-mana, karena kekuasaan merupakan satu dimensi dari relasi. Artinya, dimana ada relasi, disana ada kekuasaan. Dalam sanggar kesenian $\mathrm{Ta}^{\prime}$ Buthaan terdapat beberapa aktor yang berperan penting dalam adanya sanggar kesenian $\mathrm{Ta}^{\prime}$ Buthaan sehingga dapat dikenal oleh masyarakat banyak. Peran-peran yang dimilki oleh aktor-aktor tersebut berbeda antara satu dengan yang lainnya. Salah satunya yaitu pemilik sanggar yang memilki kuasa yang lebih dalam mengembangan kesenian $\mathrm{Ta}^{\prime}$ Buthaan agar dapat terus eksis dan dapat di kenal oleh masyarakat banyak. Relasi antar pemilik sanggar juga di butuhkan untuk dapat melestarikan kesenian $\mathrm{Ta}^{\prime}$ Buthaan karena pola untuk melestarikan kesenian berbeda-beda antara satu dengan yang lainnya. Oleh karena itu relasi antar pemilik sanggar juga bisa mempengaruhu eksistensi kesenian Ta’ Buthaan.

\section{Relasi sosial aktor dalam kesenian ta' 'buthaan}

Dalam kesenian $\mathrm{Ta}$ 'buthaan terdapat beberapa aktor yang memiliki peran penting dalam berjalannya kesenian Ta buthaan. Para aktor yang menjalani perannya sebagai seniman di dalam Ta buthaan, melakukan aksi sesuai dengan perannya masing masing. Di dalam kesenian budaya Ta buthaan sendiri terdapat empat aktor yang memiliki peran penting saat even even kesenian. Antara lain yaitu pemilik sanggar, pawang, para pemain, dan pengguna jasa hiburan. Para aktor yang muncul dalam kesenian $\mathrm{Ta}$ 'buthaan tersebut, terjadi interaksi yang saling mempengaruhi antara satu sama lain. Interaksi yang muncul tersebut menciptakan hubungan sosial yang dinamis, dan menyangkut hubungan antara orang orang secara perorangan, juga dalam kelompok manusia (Hidayat, 2013). Hubungan manusia satu dengan hubungan manusia lainnya juga hubungan manusia dalam kelompok satu dengan kelompok lainnya tidak dapat terpisahkan dari masyarakat (Wadiyo, 2006). Dalam kelompok budaya $T a$ 'buthaan itulah para aktor saling melakukan proses interaksi yang menciptakan relasi relasi sosial yang saling berhubungan.

Pemilik sanggar pada suatu kesenian adalah orang yang paling penting perannya. Seorang pemilik sanggar bertugas untuk mengatur serta memanajemen kesenian mulai dari awal hingga akhir permainan Ta buthaan. Pada kesenian Ta buthaan sendiri, seorang pemilik 
sanggar wajib memimpin jika ada sebuah even kesenian. Sang pemilik sanggar adalah yang mengetuai proses pelaksanaan kesenian Ta buthaan jika ada even. Dimulai dari mencari informasi lomba, mengkoordinasi latihan para pemainnya dan menjamin lancarnya pelaksanaan kesenian Ta buthaan.Aktor selanjutnya yang memiliki peran penting dalam kesenia Ta buthaan adalah pawang. Pawang adalah seseorang yang mempunyai ilmu dan memiliki mantra yang berguna untuk m,engobati jika para pemain $\mathrm{Ta}$ 'Buthaan mengalami kesurupan. Pawang dalam budaya Ta buthaan mempunyai peran untuk menjaga serta mengontrol kesenian tetap aman pada saat dimainkan. Dikarenakan dalam budaya $\mathrm{Ta}$ buthaan para pemainnya harus 'diisi' terlebih dahulu untuk melakukan atraksinya, disinilah tugas pawang untuk menjaga para pemainnya agar tetap terkontrol dan menghindari terjadinya kecelakaan pada saat permainanan Ta buthaan berlangsung. Untuk pemilihan pawangnya sendiri, dipilih secara faktor keturunan. Seperti yang dikatakan Pak Taufiq, ketua sanggar Ta buthaan di Desa Candijati :

" Kalau untuk pawangnya itu satu, faktor keturunan biasanya, terus yang kedua itu memang berguru dia. Itu turun temurun sebenarnya kalau adat desa ini. Ada yang belajar keluar desa ini, di luar kota “(Pak Taufiq, Ketua Sanggar Ta 'Buthaan, Desa Candijati)

Selanjutnya aktor yang memiliki peran penting dalam budaya Ta buthaan adalah para pemain. Pemain disini juga menjadi penting karena para pemain inilah yang mempertunjukkan seni kepada para penonton. Seorang aktor harus mampu menghidupkan tokoh, ruang, latar, tata busana, tata cahaya tata panggung dan sebagainya (Marciano, 2019). Pemain kesenian Ta buthaan adalah orang yang bermain dalam budaya Ta buthaan. Oleh karenanya para pemain kesenian $\mathrm{Ta}$ 'buthaan diharuskan untuk bisa menguasai perannya sesuai dengan di atas panggung agar para penonton mampu menangkap pesan yang disampaikan dalam kesenian $\mathrm{Ta}$ 'buthaan. Jumlah pemain dalam kesenian Ta buthaan tidak tentu. Tergantung dengan acara yang dilaksanakan. Jika acara yang dimainkan tidak begitu besar, maka hanya membutuhkan lima hingga sepuluh pemain. Jika acara yang dilaksanakan besar seperti arisan, maka pemain yang diperlukan adalah lima puluh orang. Seperti yang dikatakan oleh informan penelitian ini,

"Kalau untuk pemain itu 25, paten. Kalau dulu masih pake sistim arisan, itu sampe 50 an. Pemainnya senidri saya 20 an paten. Ya tapi tergantung yang mau nanggap, misalnya minta yang biasa biasa, ya saya engga bawa 25. Ya yang penting penting 
saja. Tapi kalau pemainnya saya itu, main ini bisa main itu bisa. Jadi saya engga bingung. Misalnya yang satunya sakit, sedang berpergian atau ada acara lain, biasanya pake 10, cuman pake 5. Karena yang 5 sudah menguasai. Jadi engga fokus sama satu atraksi saja” (Pak Taufiq, Ketua Sanggar Ta 'Buthaan, Desa Candijati)

Untuk pemilihan pemain, siapapun bisa ikut. Para pemain kesenian Ta 'Buthaan berisi pemuda pemuda yang ada di Desa tersebut. Namun, karena budaya Ta 'Buthaan ini adalah kesenian yang melibatkan hal mistis, maka para pemain Ta 'Buthaan harus diisi terlebih dahulu sebelum memainkan atraksinya. Para pemain yang berperan dalam kesenian Ta 'Buthaan, memiliki sikap yang membudaya pada diri masing masing pemain. Sikap sikap yang dimiliki para pemain $\mathrm{Ta}$ 'Buthaan menjadikan para pemain sadar akan pentingnya nilai kesadaran budaya Ta 'Buthaan. Sikap - sikap yang ada pada diri pemain antara lain :

\section{Antusias}

Sikap antusiasme merupakan sikap keinginan yang benar benar ingin dilakukan dari diri individu. Antusiasme merupakan bentuk semangat para individu dalam melakukan hal yang ingin dilakukan. Sikap antusias ini bisa dilihat pada para pemain kesenian Ta 'Buthaan. Dapat ditemukan para pemain yang sangat antusia dalam berpartisipasi dan ikut pada setiap even ataupun lomba guna memainkan budaya $\mathrm{Ta}$ 'Buthaan

\section{Loyal}

Sikap loyalitas adalah sikap yang harus dimiliki oleh setiap individu yang berada pada suatu kelompok. Sifat loyal dibangun dengan usaha yang tidak mudah. Perlu adanya perjuangan yang dilakukan untuk memiliki sifat tersebut. Loyalitas tidak dapat dibeli oleh uang. Sikap loyal ini bisa dilihat pada para pemain kelompok kesenian Ta 'Buthaan. Sikap tersebut dilihat dari bagaimana para pemain tersebut selalu serius dalam berlatih ketika ada event ataupun lomba. Sikap loyalitas tersebut menjadi salah satu bentuk kesetiaan para pemain $\mathrm{Ta}$ 'Buthaan pada kesenian tersebut.

\section{Sukarela}

Sukarela adalah sikap dimana para individu rela melakukan sesuatu yang mengorbankan miliknya demi kepentingan orang lain. Sikap ini menjadi hal yang garus dimiliki pada masyarakat saat ini. Suka rela merupakan bentuk sukarelawan dalam suatu kelompok demi kepentingan kelompok tersebut. Sikap suka rela ini bisa ditemukan pada para pemain $T a$ 'Buthaan, bisa dilihat para pemain di sanggar $T a$ 'Buthaan, bayaran untuk para pemain kesenian $T a$ 'Buthaan tidak begitu banyak. Namun, mereka tetap ikut dan bermain $\mathrm{Ta}$ 'Buthaan demi terjaganya kebudayaan $\mathrm{Ta}$ 'Buthaan. 


\section{Kreatif}

Sikap kreatif disini merupakan bentuk dari kemampuan individu dalam menciptakan sesuatu dengan sekretif mungkin. Sikap kreatif menjadikan setiap individu dapat menciptakan sesuatu dengan sumber daya yang minim, namun dapat menghasilkan sesuatu yang luar biasa. Sikap kreatif tersebut dapat ditemukan pada para pemain Ta 'Buthaan. Seperti yang dianilis sebelumnya bahwa sanggar $\mathrm{Ta}$ 'Buthaan di desa Candijati tidak memiliki sumber dana yang besar. Maka dalam membuat kostum pun mereka menfaatkan sumber daya seadanya. Kostum yang dihasilkan pun memiliki kualitas yang layak untuk digunakan. Juga mudah untuk dibuat.

Aktor selanjutnya yang berperan pada kesenian Ta 'Buthaan adalah pengguna jasa hiburan. Pengguna jasa hiburan ini adalah orang yang memakai jasa kesenian Ta 'Buthaan, untuk mengisi acara yang diadakan. Biasanya lama bermain $T a$ 'Buthaan bergantung pada besar dan kecilnya acara yang dimainkan. Semakin besar acara yang ditanggapi, maka penampilan dalam bermain dan alur cerita $T a$ 'Buthaan akan dibuat lama. Jika acara yang didatangi tidak begitu besar, maka lama atraksi $\mathrm{Ta}$ 'Buthaan dibuat sebentar. Begitu pula para pemain kesenian Ta 'Buthaan menyesuaikan dengan besar kecilnya acara yang ditanggap.

“Tergantung yang nanggap, normalnya itu biasanya 3-4 jam. Itu dibikin kolaborasi. Saya yang bikin kadang dibuat alur cerita. Cerita cerita sejarah itu yang saya pakai. Kadang orang orang itu engga semangat kalau cuman liat ta butaannya engga ada kolaborasi. Saya bikin cerita. Kayak wayang gitu." (Pak Taufiq, Ketua Sanggar Ta 'Buthaan, Desa Candijati)

Di dalam $T a$ 'Buthaan, para pemain yang memainkan kesenian tersebut melakukan beberapa ritual sebelum atraksi dilakukan. Karena $T a$ 'Buthaan merupakan budaya yang masih kental dengan adat ghaib, maka ritual pun dilakukan sebelum melakukan pertunjukan. Seperti yang kita tahu saat ini, dalam menyelenggarakan suatu prosesi, berbagai persyaratan harus sesuai kaidah kaidah ritual yang telah mentradisi tidak boleh ditinggalkan, baik oleh pemeran ataupun penyelenggara (Andri R.M., S.S., M.A, 2016). Para pemain kesenian Ta 'Buthaan sebelum melakukan pertunjukkan harus 'diisi' terlebih dahulu. 'Diisi' disini maksudnya adalah para pemain yang memainkan budaya $T a$ 'Buthaan dimasuki oleh mahluk halus yang dipandu oleh pawang Ta 'Buthaan. Hal tersebut dilakukan karena kostum yang dipakai oleh pemain $T a$ 'Buthaan sangatlah berat, serta rutenya yang jauh maka para pemain 
harus 'diisi' terlebih dahulu agar dapat mengangkat beban kostum yang beratnya hingga $5 \mathrm{~kg}$ dengan melewati rute hingga $20 \mathrm{~kg}$. Untuk pemain yang 'diisi' dipilih yang sudah pernah 'diisi' sebelumnya. Karena lebih mudah untuk dimasukkan mahluk halus oleh pawang. Sedangkan untuk pemain yang belum pernah 'diisi' harus melakukan ritual puasa terlebih dahulu.

Interaksi yang muncul antar anggota pemain budaya $T a$ 'Buthaan membangun hubungan hubungan sosial yang saling berkaitan antar anggotanya. Para pemain yang saling bermain, berlatih bersama dengan anggota lainnya menciptakan kesolidaritasan yang kuat dan menciptakan kesadaran akan pentingnya menjaga kelestarian kesenian Ta 'Buthaan. Dengan adanya kesenian $\mathrm{Ta}$ 'Buthaan, menjadikan para pemain dalam kelompok budaya $\mathrm{Ta}$ 'Buthaan membangun kepentingan yang sama demi terjaganya budaya Ta 'Buthaan. Dalam kesenian Ta 'Buthaan individu - individu yang tergabung menjadi satu kelompok sanggar $T a$ 'Buthaan, menciptakan interaksi sosial yang membangun kepentingan bersama. Adanya kesenian $T a$ 'Buthaan berguna sebagai sarana para pemain dalam kelompok Ta 'Buthaan menjaga kelestarian budaya Ta 'Buthaan.

\section{Relasi kekuasaan dalam bingkai kesenian ta'butha an}

Saat ini kekuasaan telah beroperasi secara produktif an reproduktif, menyebar dalam praktik kedisiplinan terhadap tubuh individu, dalam kesenian ta'butha, an pemilik sanggar memiliki relasi kekuasaan yang menguasai setiap peran peran dibawahnya, mengontrol fungsi fungsi dalam relasi sosial (Kamahi, 2017). Kesenian ta'butha an terdapat beberapa peran didalam struktur yang dimiliki oleh suatu sanggar, yaitu pemilik sanggar, pawang, dan pemain. Pemerintah desa juga memiliki peran dalam mengembangkan kesenian ta'bhuta an, di Desa Kamal Kecamatan Arjasa, kesenian ta' bhuta an menjadi kesenian khas desa dan setiap tahun nya terdapat sebuah acara yakni resik desa. Resik desa menjadi tradisi yang dilakukan secara turun temurun hingga saat ini dan pemerintah desa pun ikut membantu dalam pengembangan kesenian daerah tersebut.

Peran peran tersebut saling berhubungan dalam bingkai kesenian ta' butha an. Pemilik sanggar yang memiliki kekuasaan dalam mengatur peran peran dibawahnya. Dalam proses penampilan atau ritual ritual yang akan dijalankan oleh kelompok kesenian adalah otoritas yang dimiliki oleh pemilik sanggar. Masing masing peran memiliki fungsi yang saling berhubungan dan ketergantungan satu sama lain, kemudian salah satu peran memiliki tingkatan yang lebih berkuasa dengan melakukan cara mereka sendiri, Pemilik sanggar 
menumbuhkan rasa cinta akan kesenian khas daerah kepada para pemuda yang menjadi pemain pemain dalam kesenian ta'butha an, dengan adanya rasa cinta tersebut hingga pemuda yang memiliki jiwa semangat juang dan pantang menyerah melestarikan tradisi kesenian walaupun tanpa diberi imbalan yang besar, jika tidak ada tanggapan mereka sering kali melakukan penampilan di beberapa daerah meskipun hanya diberi imbalan berupa makanan saja.

"jika tidak ada job nawarin tidak usah bayar wes buk, pokok di dekek nang umae sampean, gitu sangking kelamaan ndak tanggapan pokok dikek $i$ mangan, dijemput, diantar, gitu." (Pak Taufiq, Ketua Sanggar Satria Muda)

Menurut foucault, subjek berhak memilih atau menolak berdasarkan naluri subjektif. Dalam kasus ini relasi kekuatan terjadi secara mutlak. Strategi dari aktor yang berkuasa yang menentukan susunan atau struktur dalam sanggar kesenian Ta'Buthaan. Tidak ditemukan perlawanan yang terjadi strategi pertujukan diatur oleh pemilik sanggar kesenian Ta'Buthaan. Strategi strategi yang dibuat oleh pemilik sanggar sangat menentukan bagaimana berpengaruh nya pada eksistensi dari kesenian ta'butha an sendiri. Masyarakat melihat dan mengapresiasi kemudian mengundang nya kembali dengan syarat biaya yang telah ditetapkan sebelumnya. Pemilik sanggar mendapatkan keuntungan dari undangan penampilan tersebut, jika seseorang akan menyewa jasa harus menghubungi ke pemilik sanggar terlebih dahulu kemudian pemilik sanggar memilih siapa saja yang akan menjadi pemain dalam penampilan yang akan dipertontonkan. Hal tersebut menunjukkan bahwa kekuasaan tertinggi dalam sebuah sanggar berada pada pemilik sanggar. Pemilik sanggar yang memulai mengembangkan sebuah kesenian, merekrut pemuda agar lebih mencintai karya karya tradisi khas daerah, mencari relasi sejak dini untuk mengembangkan sebuah kesenian ta'butha'an hingga terus berkembang.

\section{KESIMPULAN}

Kesenain Ta'Buthaan merupakan sebuah kesenian tertua di daerah Jember Utara. Kesenian ini seringkali di identikkan dengan pembebasan/pembersihan dari bala/musibah. kesenian ini biasanya digunakan pada saat acara resik desa, dan juga ketika panen raya dilangsungkan. Di daerah Jember Utara terdapat sekitar 23 lebih kelompok sanggar kesenian ta' Butha'an. Di desa Kamal kesenian ta' Butha'an masih tetap dilestarikan, pemuda di desa 
tersebut turut serta dalam menampilkan kesenian $t a^{\prime}$ Butha'an tersebut dalam event-event yang ada. kesenian $t a$ ' Butha'an ditampilkan secara rutin setiap tahun setelah panen raya dalam acara resik desa. Tidak hanya pada saat resik desa saja kesenian ta' Butha'an tersebut ditampilkan, namun kesenian $t a$ ' Butha'an juga turut serta dalam event-event seperti karnaval di luar kota yang dimaksudkan agar kesenian ta' Butha'an dapat berkembang dan dikenal oleh banyak orang di luar kota Jember.

Dalam kesenian Ta 'Buthaan terdapat beberapa actor yang memiliki peran penting yang bermain dalam budaya Ta 'Buthaan. Aktor aktornya antara lain pemilik sanggar, pawing, para pemain, dan pengguna jasa hiburan. Untuk para pemain kesenian Ta 'Buthaan memiliki sikap sikap yang muncul pada masing masing pemain. Sikap sikap tersebut yaitu, antusias, loyal, suka rela, dan kreatif. Interaksi interaksi yang dibangun antar pemain kebudayaan Ta 'Buthaan membangun hubungan relasi yang menciptakan kesolidaritasan. Kesenian ta'butha an memiliki struktur yang didalam nya terdapat peran peran yang saling berhubungan, dalam struktur peran tersebut ada salah satu peran yang berkuasa dalam sebuah sanggar kesenian, yaitu pemilik sanggar. Karena seorang pemilik sanggar memiliki wewenang dalam mengontrol setiap individu atau menentukan siapa saja orang yang akan ditampilkan dalam sebuah bingkai kesenian ta'butha an tersebut. 


\section{DAFTAR PUSTAKA}

Saputri, L. (2019). Pengaruh Budaya Pandalungan pada Bentuk Penyajian Kesenian Can Macanan Kadduk. INVENSI, 4, 167-183.

Jannah, R. (2012). Jember Fashion Carnival: Konstruksi Identitas dalam Masyarakat Jaringan. Jurnal Sosiologi MASYARAKAT , 135-151.

Af, A. K. (2012). KONSEP KEKUASAAN MICHAEL FOUCAULT. Jurnal Tasawuf Dan Pemikiran Islam, 131-149.

Andiyanto. (2003). Sejarah Budaya Jember Utara. Jember, Jawa Timur, Jember.

Eska Wiedyana, N. S. (2018). EKSISTENSI PERTUNJUKAN CAN MACANAN KADDUK' PAGUYUBAN BINTANG TIMUR DI KABUPATEN JEMBER. GREGET, 17.

Hidayah, W., \& Azizah, N. (2018). Pengembangan Wawasan Kebudayaan Melalui Teks Cerita Rakyat "Ta'Buthaan" dengan Model Pembelajaran Kooperatif Type Jigsaw. PS PBSI FKIP Universitas Jember, 263-276. (Diakses pada 1 Desember 2019)

Hidayat, Y. (2013). HUBUNGAN SOSIAL ANTARA ETNIS BANJAR DAN ETNIS MADURA. JURNAL KOMUNITAS, 87-92.

Wadiyo. (2006). Seni sebagai Sarana Interaksi Sosial (Art as a Tool of Social Interactions). HARMONIA JURNAL PENGETAHUAN DAN PEMIKIRAN SENI, VII No.2.

Marciano, R. (2019). Pengembangan Teknik Peran Seorang Aktor Untuk Pementasan Monolog Melalui Sistem Stanislavski dalam Buku an Actor Prepares and Building a Character. SATWIKA: Jurnal Kajian Budaya dan Perubahan Sosial , 69-86.

Andri R.M., S.S.,M.A. , L. (2016). SENI PERTUNJUKAN TRADISIONAL DI PERSIMPANGAN ZAMAN: STUDI KASUS KESENIAN MENAK KONCER SUMOWONO SEMARANG. HUMANIKA, 25-31.

Kamahi, U. (2017). Teori Kekuasaan Michel Foucault : Tantangan Bagi Sosiologi Politik. Jurnal Al-Khitabah, 117 - 120.

Susilo, D. R., Saripudin, D., \& Moeis, S. (2018). PERKEMBANGAN SANGGAR SENI TARI TOPENG MULYABHAKTI DI DESA TAMBI. FACTUM: JURNAL SEJARAH DAN PENDIDIKAN SEJARAH, 53-66. 